\title{
FELSŐOKTATÁSI JELENTKEZÉSEK - ÚJ HALLGATÓK, ÚJ MÓDSZEREK?
}

\section{HIGHER EDUCATION APPLICATIONS - NEW STUDENTS, NEW METHODS?}

\author{
Kuráth Gabriella', Sipos Norbert ${ }^{2}$ \\ 'PhD, címzetes egyetemi docens, tanácsadó, Pécsi Tudományegyetem Rektori Kabinet \\ kurath.gabriella@pte.hu \\ ²PhD, egyetemi adjunktus, Pécsi Tudományegyetem Közgazdaságtudományi Kar \\ sipos.norbert@ktk.pte.hu
}

\begin{abstract}
ÖSSZEFOGLALÁS
A felsőoktatásban bekövetkezett nemzetközi és hazai változások az elmúlt évtizedekben jelentősen átalakították a felsőoktatási intézmények működésének mindennapjait. Az általános trendek, mint a népesség összetétele, az elektronikusan elérhető anyagok bővülése, a tömegesedés mellett a társadalmi igények is megváltoztak, ma már elvárják az adott képzés közvetlen munkaerőpiaci hasznosulását.

Tanulmányunkban egyrészt bemutatjuk az utóbbi egy évtizednek a magyar felsőoktatás hallgatói bázisában bekövetkezett jelentősebb változásokat. Másrészt a Pécsi Tudományegyetemen a felvételizők körében folytatott 2015/16-os és 2016/17-es felmérésekre érkezett 1396 válasz segítségével mutatjuk be az új generációk döntéseit befolyásoló elemekben azonosítható elmozdulásokat. Megállapíthatjuk, hogy továbbra is a költségérzékenység-tudatosság, a kényelem és a presztízs a meghatározóak, ugyanakkor lényegesen nagyobb a magasabb szintű szolgáltatások iránti igény, valamint magasabb a költségérzékenység-tudatosság mértéke is.

A felsőoktatási jelentkezési döntések elemzésekor a bemenethez szorosan kapcsolható a kimenet, valamint az egyéni döntéseket befolyásoló tényezők vizsgálata.
\end{abstract}

\section{ABSTRACT}

The international and domestic changes in higher education in the last decades have significantly transformed the everyday life of higher education institutions. The general trends, such as the composition of the population, the expansion of electronically available materials, the massification, and the social needs have also changed. Nowadays, the formation-related direct labor-market utilization became a basic expectation.

In our study, on the one hand, we present the major changes in student base of Hungarian higher education in the last decade. On the other hand, we will demonstrate the identifiable changes of the new generations during their institution-choice decision-making processes with the help of 1396 responses to the researches carried out at the University of Pécs among the higher education applicants of 2015/16 and 2016/17. We can conclude that cost-sensitiveness-consciousness, comfort, and prestige remain decisive, and also, the level of awareness is higher.

When analyzing higher education application choices, the input can be closely linked to the output and the factors influencing individual decisions. 
Kulcsszavak: felsőoktatás, jelentkezések, faktoranalízis, generációk

Keywords: higher education, applications, factor analysis, generations

\section{HAZAI FELSŐOKTATÁSI KIHIVIÁSOK}

A magyar felsőoktatásra is hatnak a világban zajló megatrendek, így például a globalizáció, a gyors technológiai változások, a demográfiai folyamatok és a változó társadalmi igények, valamint a hazai jellemzőket meghatározó tényezők is. Külön ki kell emelnünk a jelentkezések mennyiségi és minőségi változását, így a hazai jelentkezői piac beszükülésével is egyre fontosabb foglalkozni. Ugyanakkor természetesen a bolognai rendszer bevezetésével, az intézmények közötti átjárhatóság, az egyes képzések elfogadásának egységesítése révén a nemzetközi hallgatói mobilitás is megerösödött, és kiemelt területté vált hazánkban is.

Az elmúlt időszakban a magyarországi helyzetet áttekintve nagyon sok elemző munka született, ezek alapján számos terület változását érzékeljük. A tanulmány terjedelmi korlátai miatt a hazai felsőoktatási kihívásokra fókuszálunk, ezen belül is két területet mutatunk be, egyrészt a jelentkezések alakulásának változását, másrészt a jelentkezőket a döntésben befolyásoló külső tényezők alakulását az elmúlt évtizedben. Inkább csak felvetünk témákat, kérdéseket, illetve javaslatokat fogalmazunk meg, és ajánljuk továbbgondolásra.

\section{FELSŐOKTATÁSI JELENTKEZÉSEK}

Úgy gondoljuk, hogy az egyes intézmények versenyképességét közvetlenül tükrözi, hogy milyen nagyságú és összetételủ a felvételiző diákok köre, ezért a teljesség igénye nélkül bemutatjuk a felsőoktatási jelentkezések alakulását.

\section{Módszertan}

Az adatok elemzésekor döntően az Oktatási Hivatal által kezelt és a rendelkezésünkre bocsátott felvételizői adatbázisokat használtuk fel a 2005/06-2015/16-os felvételi időszakokra vonatkozóan. Ez tartalmazza az összes magyarországi felsőoktatási jelentkezést, a normál, keresztféléves és pót jelentkezési időszakokat is, de nem tartalmazza a szakirányú továbbképzésre és a doktori programra való jelentkezéseket.

Az elmúlt tízéves időszakban számos változás történt, az intézményi összevonásoktól kezdve egyes képzések, karok vándorlásán át a felvételi jelentkezé- 
si eljárásig bezárólag, ami nagymértékben megnehezíti az adatok kezelését, az elemzés elvégzését, ezért az adatokat tisztítottuk, így a felsőoktatási intézmények pozícióját jól leképező, azonos alapon lehet elemezni az információkat.

\section{Jelentkezôi létszám}

A felvételizők első helyen történő jelentkezése megmutatja, hogy mi a legalapvetőbb szándékuk, milyen területen, hol szeretnének tanulni, ezzel szemben az összes jelentkezés száma általánosabb, objektívebb képet ad a felsőoktatási intézmény, az adott kar vagy a szak iránti társadalmi szintü érdeklődésről. Mindkét dimenziót számos hatás befolyásolja, jelen keretek között nem lehet, és nem is célunk mindezek elkülönítése, azok lehetséges befolyásoló mértékének becslése, az egyes megragadható fóbb hangsúlyokra fókuszálunk.

A felsőoktatásba jelentkezők, valamint az érettségizők létszámát vizsgálva 2002/03-2017/18 között látványos és egyértelmü elmozdulások azonosíthatóak. Egyrészt a normál felvételi eljárás alapját képező középiskolában érettségizők száma nagymértékben visszaesett. Ez részben a népesség általános elöregedésére, részben a fiatalok számának csökkenésére vezethető vissza, ugyanakkor biztos, hogy egyéb tényezők is szerepet játszottak. Polónyi István (2016) kiemeli, hogy a felsőoktatásba újonnan belépő hallgatók számának csökkenése tíz évre visszamenőleg kétszer akkora volt, mint a korosztályi létszámban azonosítható visszaesés, amely mellett csupán plusz tényezőként jelenik meg az államilag finanszírozott hallgatóknál látható 20\%-os visszaesés. Ez a hatás is megragadható a számokban, így látható, hogy az oktatáspolitikában bekövetkező irányváltás (számos képzés költségtérítéssé alakítása) 2011-től erőteljesen megjelenik. 2010-2015 között a jelentkezők/felvettek számában történő csökkenés jelentősebb, mint a visszaesés az érettségiző korosztály létszámában. A felsőoktatásba jelentkezők létszámának gyors, drasztikus csökkenése megállt, lényegében stagnál 2014/15 és 2017/18 között, azonban az érettségizők száma enyhén, de folyamatosan csökken (1. ábra).

Mindezek azt is mutatják, hogy a felsőoktatási intézményeknek újra kell gondolniuk a stratégiájukat, a hagyományos bázisokra építkezés egy elnyújtott leépítést, zsugorodást jelent. Az érettségizők számában valószínüsíthető a stabilizálódás, így lehetséges, hogy a jelentkezők száma is emelkedni fog, amennyiben a bejutási feltételek nem változnak (Polónyi, 2018).

Részletesebb elemzések olvashatóak A magyar felsőoktatás egy évtizede 2008-2017 kötetben (Kovács-Temesi, 2018).

A két fő tagozaton, a nappali és levelező képzésben részt vevőknél eltérően zajlott le a változás. Míg a levelezőknél a 2005/06-os időszak - és az azt megelöző időszakban éppen az Európai Unióhoz való csatlakozás, az elmaradt képzések pótlása által kifejtett felfutás - után azonnali a csökkenés; addig a nappalisok körében csak a már említett 2011/12-es akadémiai év után látható ez. 


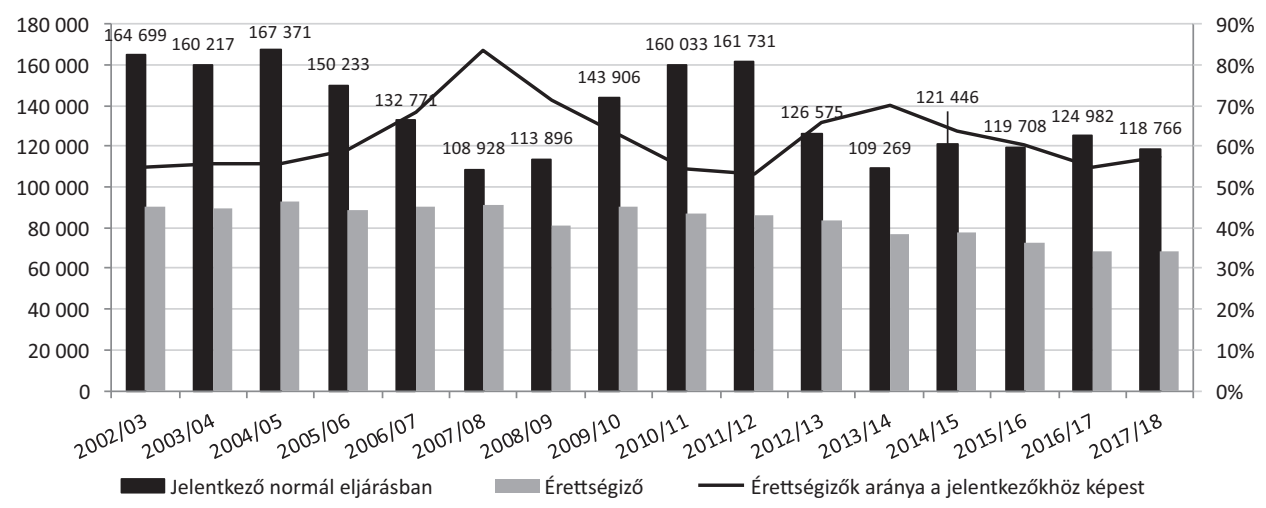

1. ábra. A felsőoktatásba normál eljárás keretén belül jelentkezők számának alakulása, az érettségizők számának figyelembevételével (fö)

Oktatási Hivatal, www.felvi.hu és www.ksh.hu alapján a szerzők saját szerkesztése

A regionális különbségek is jelen vannak, a beiskolázási körzetek/vonzáskörzetek vizsgálatakor évek óta egyértelmű tendenciák figyelhetők meg. Polónyi (2018) tanulmányában összegzi, hogy jól érzékelhetően növekedett a felsőoktatásba történő 1. helyes jelentkezéseknél a fővárosi intézmények elsőbbsége, 2017-re már a jelentkezések több mint 50\%-a budapesti intézménybe történik. A felvettek létszámadataiból világosan látszik, hogy a 2010-es felsőoktatás-politikai irányváltás nyomán bekövetkezett felsőoktatási létszámmegszorításnak a vidéki felsőoktatás az egyértelmü vesztese (Kuráth-Sipos, 2019). Mindezek mellett fontosnak tartjuk kijelenteni, hogy a felsőoktatásban való részvétel növekvő hazai mértékét várjuk közép- és hosszú távon.

\section{A JELENTKEZÉST BEFOLYÁSOLÓ TÉNYEZŐK}

A felsőoktatásba jelentkezőket befolyásoló elemekben bekövetkezett változásokat érdemes megvizsgálnunk, ezeket a hatásokat egy rövid szakirodalmi összegzés mellett a Pécsi Tudományegyetemen folytatott 2016-os és 2017-es országos „felvételizők felmérés" eredményei alapján mutatjuk be.

\section{Változó fiatalok és az intézményválasztás}

Marketing szempontból a fiatalság az egyik legnehezebben kezelhető csoport, hiszen számos alcsoporttal rendelkezik, és a piac gyorsan változik.

Napjainkban már a magyar hallgatók is egyszerre igénylik a jó minőséget, a megbízhatóságot, az egyéni igényekhez igazítást, mindezt természetesen ala- 
csony árakon. A fentiekkel összefüggésben változtak a jelentkezési célok, motivációk, amelyek jelentős hatással vannak a felsőoktatási kommunikációra, a vonzáskörzetek alakulására is.

Napjainkban a magyar marketingszakma nehézkesen próbál együtt haladni a megváltozott fogyasztóval, befolyásolni a döntéseit, nehéz kapaszkodókat találni és az erre kiadott pénzösszegek hatékonyságát bizonyítani (Törőcsik, 2016), ez fokozottan igaz a fiatal korosztályra.

Magyarországon több országos kutatás is zajlott az elmúlt években a fiatal generáció megértésére, illetve jövőbeli elképzeléseire vonatkozóan (Bernschütz et al., 2016; Medián, 2017; Székely-Szabó, 2016; Törőcsik, 2015). A felmérésekből láthatjuk, hogy ez a változó célcsoport nagyon sok kérdéssel foglalkozik, ugyanazokkal az alapgondokkal küzd, mint európai társai, illetve mint a korábbi generációk, de ezt elfedi a körülmények újszerüsége és az új gondok ismeretlensége. Természetesen a magyar fiatalok a társadalom átlagához képest gyorsabb életet élnek, és az új technikai világot is jobban értik, ezáltal megfordult a tudás átadásának iránya, az információszerzés és a megosztás is változott. Ezek a változások a magyar oktatásban is teljesen más szemléletet igényelnek, hiszen az újabb és újabb technológiát használó hallgatói generációk már más igénnyel jelennek meg, és ez a technikai kérdésektől a pedagógiai kérdésekig mindenre vonatkozik.

Természetesen a felsőoktatási döntésekre is hatással vannak ezek a változások. Mivel a felsőoktatási tanulmányok folytatása jellemzően hosszabb időszakot ölel fel, ezért az intézményválasztás komoly, bonyolult döntés, és nagyon sok kérdés merül fel. Több, a hazai felvételizők döntéseit vizsgáló felmérés is zajlott az elmúlt években (Kuráth, 2008; Olsovszkyné Némedi, 2014; Polónyi, 2018; Rámháp, 2017; Rechnitzer, 2010; Törőcsik, 2015), ezek szintetizálásából kiderül, hogy a jelentkező először az érdeklődési körének megfelelő szakot/képzést keresi, és csak ezt követően választ intézményt, várost. A fenti felmérések alapján az intézmények megítélésének főbb szempontjai (kutatásonként jellemzően egy-két rangsorbeli hely különbséggel) az intézményi hírnév, a piacképes diploma, az elhelyezkedési lehetőségek, a lakóhelyhez való közelség - alacsonyabb megélhetési és lakhatási költségek, valamint a vonzó, élhető város, ahol az intézmény található.

\section{A jelentkezést meghatározó tényezők}

A 2015/16-os és a 2016/17-es időszakban felvételizők jellemzöit mutatjuk be a Pécsi Tudományegyetem által folytatott országos kérdőíves vizsgálat alapján (Kuráth et al., 2016, 2017). A kérdőíveket a középiskolák végzős diákjai számára juttattuk el, egyetemi nyílt napokon, valamint regionális és országos felsőoktatási kiállításokon töltettük ki. A visszaérkezett és ellenőrzött kérdőívekből 1396 db volt értékelhetö. 
A válaszadók döntően az adott évben vagy egy éven belül érettségiztek, 65\%-uk nő, mely megegyezik az alapsokaság arányával, többségük nappali tagozatra szeretne jelentkezni, ezért a minta megoszlása alapján a nappali, alapképzésre jelentkezők magatartását vizsgálhatjuk.

Jelen tanulmányban a felsőoktatási intézmény választásának szempontjait elemezzük, amely során SPSS-szoftver segítségével faktoranalízist alkalmaztunk. A kiválasztott felsőoktatási intézmény választását meghatározó kérdéseket 1-től 5-ig, az iskolai osztályzatoknak megfelelően értékelték a válaszadók.

A faktorelemzés magas megbízhatóság mellett végezhető el, a 22 és 18 változóból a három-három végső változót különítettük el az alkalmazott módszertannak köszönhetően. Az egyes faktorok által magukba foglalt területek a táblázatban olvashatóak.

1. táblázat. A 2015/16-os és 2016/17-es PTE-felvételizők kutatás válaszadóit befolyásoló tényezők a felsőfokú intézménybe való jelentkezés során

\begin{tabular}{|l|c|c|c|}
\hline \multicolumn{1}{|c|}{$\begin{array}{c}\text { Felsőoktatási intézmény } \\
\text { választását befolyásoló tényezők }\end{array}$} & $\begin{array}{c}\text { Költségérzékenység- } \\
\text { tudatosság }\end{array}$ & Kényelem & $\begin{array}{c}\text { Presztízs- } \\
\text { orientáció }\end{array}$ \\
\hline A város vonzó & & $\mathrm{X}$ \\
\hline Rangsorban jó helyen szerepel & & $\mathrm{X}$ \\
\hline Pezsgő az egyetemi élet & & $\mathrm{X}$ \\
\hline Jó hírü & & $\mathrm{X}$ \\
\hline Jók a nemzetközi kapcsolatok & & $\mathrm{X}$ & \\
\hline Közel van a lakóhelyhez & $\mathrm{X}$ & \\
\hline A család elvárásainak megfelel & $\mathrm{X}$ & $\mathrm{X}$ \\
\hline Könnyü bekerülni & $\mathrm{X}$ & \\
\hline Könnyủ elvégezni & $\mathrm{X}$ & \\
\hline A barátok is ezt választják & $\mathrm{X}$ & & \\
\hline A diploma segíti az elhelyezkedést & $\mathrm{X}$ & \\
\hline Gondozzák a tehetségeket & $\mathrm{X}$ & \\
\hline Érdeklődésének megfelelőt tanul & $\mathrm{X}$ & \\
\hline Alacsony a tandíj & & & \\
\hline Alacsony a megélhetési költség & & & \\
Állami ösztöndíjas helyek száma & & & \\
\hline Jó ösztöndíjak vannak & & & \\
\hline
\end{tabular}

Kuráth et al., 2016, 2017 alapján saját szerkesztés 
Ezek a faktorok nagymértékben megegyeznek egy tíz évvel ezelőtti felmérésben tett megállapításokkal (Kuráth, 2008), ugyanakkor elmozdulás azonosítható a költségérzékenység-tudatosság felé. Ennek bemutatására érdemes megvizsgálni a faktorértékek változásait a különböző kereszttényezők mentén:

- Az érettségi évét vizsgálva az adott évben érettségizőknél a költségérzékenység-tudatosság és a presztízs a legmagasabb, míg a kényelem a később érettségizőknél lényegesen magasabb. A már érettségivel rendelkezőknél a presztízs és a kényelem játszik jelentősebb szerepet.

- Van különbség a nemek tekintetében is, azaz a férfiak kevésbé költségérzékenyek-tudatosak, mint a nők (utóbbiaknak ez a legmagasabb érték a három faktor közül). A férfiaknak lényegesen meghatározóbb a kényelem, és nem sokkal lemaradva a presztízsfaktorok. A nőknél a kényelem az utolsó helyen szerepel, a presztízs ugyanakkor bír még némi meghatározó erővel.

- A lakóhely szerinti bontásnál a fővárosiak számára a presztízs és a kényelem az elsődleges tényezők. A Budapesten kívüli nagyvárosban élők esetében is jelentős, meghatározó tényező a kényelem, ugyanakkor már a költségérzékenység-tudatosság is jobban megjelenik a választásuk során. A kisvárosokban élőknél a költségérzékenység-tudatosság és a presztízs játszanak jelentősebb szerepet, míg a falvakban lakóknál magas a költségérzékenység-tudatosság tényező értéke, és második helyen van csak a presztízs, míg a kényelemmel szemben elutasítóak.

A fentiek alapján úgy gondoljuk, hogy a leendő hallgatók jelentkezését befolyásoló tényezők változásával fejleszteni kell a marketinginformációs rendszer vezetői döntéstámogató szerepét.

\section{ÖSSZEGZÉS}

A demográfiai apály, a csökkenő jelentkezések, az újabb és újabb jelentkezői generációk változói igényei arra ösztönzik a felsőoktatási intézményeket, hogy kitörési pontokat keressenek. A verseny erősödik, ezzel összhangban a stratégiai döntések és a marketing szerepe felértékelődik, amelynek egyik legfontosabb területe az információgyüjtés, elemzés. A marketingstratégiák kialakításánál egyre komolyabban kell figyelembe venni a fiatalok megváltozott magatartását. Azonban a mai adatrengetegben az újabb adatok átadása már nem érték, helyette olyan segítő rendszer kell, amely a vezetői döntés-előkészítést, az intézményi érintettekhez történő eljuttatást, a bevonódást támogatja, ezáltal jelentős versenyelőnyt biztosít az intézménynek. A siker előfeltétele a jelentkezői csoportok és döntéstámogatóik minél jobb megismerése. 
A költségérzékenység-tudatosság szempont felértékelődése kapcsán kiemelt feladatként jelenik meg a felsőoktatás és a munkaerőpiac összhangjának megteremtése, amelyet elvár a felsőoktatásban érintett összes szereplö, ez egy nagyon sokrétü témakör, a képzésektől a karriertámogatáson át a szolgáltatásokig sok kérdést felvet. Az információszerzés oldaláról megközelítve a kérdést, a Diplomás Pályakövető Rendszer kiépítése ezt a területet próbálja mérni (Veroszta, 2018), továbbá az aktív és végzett hallgatói felmérések országos és intézményi összehasonlító eredményei is hasznosíthatóak, illetve komoly támogatást adhatnak a jelentkezői kör elemzéséhez is.

\section{IRODALOM}

Bernschütz M. - Dörnyei K. - Nováky E. (2016): A Z-generáció a jövőröl - empirikus vizsgálat eredményei. In: Tóth A. - S. Gubik A. (szerk.): Magyarország 2025-ben és kitekintés 2050-re. Tanulmánykötet Nováky Erzsébet 70. születésnapjára. Budapest: Arisztotelész Kiadó, 63-89. http://unipub.lib.uni-corvinus.hu/2514/

Kováts G. - Temesi J. (szerk.) (2018): A magyar felsőoktatás egy évtizede 2008-2017. Budapest: Budapesti Corvinus Egyetem, http://unipub.lib.uni-corvinus.hu/3302/

Kuráth G. (2008): A hazai felsőoktatási intézmények regionális hatásának vizsgálata a beiskolázási marketingmunkában. Tér és Társadalom, 22, 4, 95-110. https://tet.rkk.hu/index.php/TeT/article/view/1141

Kuráth G. - Héra-Tóth A. - Sipos N. (2016): PTE Felvételi kutatás 2016. Pécs: Pécsi Tudományegyetem

Kuráth G. - Héra-Tóth A. - Sipos N. (2017): PTE Felvételi kutatás 2017. Pécs: Pécsi Tudományegyetem

Kuráth G. - Sipos N. (2019): A hazai felsőoktatási jelentkezési döntések változása. A regionális hatás. Tér és Társadalom, 33, 1, 173-184. https://tet.rkk.hu/index.php/TeT/article/view/3073

Medián (2017): A Z-generáció jelene és jövőképe. https://www.hrportal.hu/hr/mit-akar-elerni-a-zgeneracio-a-munka-vilagaban-20171019.html

Olsovszkyné Némedi A. (2014): Hallgatói és munkaerö-piaci elégedettségi vizsgálatok a felsőoktatási marketingben. PhD-értékezés. Kaposvár: Kaposvári Egyetem, http://phd.ke.hu/ fajlok/1403774963-doktori_ertekezes_olsovszkyne_n_a_pdf

Polónyi I. (2016): Felsőoktatás a koncepciók keresztútján. Köz-gazdaság, 11, 2, 209-222. https:// core.ac.uk/download/pdf/43009510.pdf

Polónyi I. (2018): A hazai felsőoktatás elmúlt 10 évének néhány gazdasági és felvételi jellemzője. In: Kováts G. - Temesi J. (szerk.): A magyar felsőoktatás egy évtizede 2008-2017. (NFKK Kötetek 2.) Budapest: Budapesti Corvinus Egytem, http://oktatoihalozat.hu/wp-content/uploads/2018/03/Mibe-ker\%C3\%BCl-egy-diploma-Pol\%C3\%B3nyi-Istv\%C3\%Aln.pdf

Rámháp Sz. (2017): Felsőoktatási továbbtanulási motivációk Magyarországon a változó ifjúság és a piacosodó felsőoktatás tükrében. PhD-értekezés. Győr: Széchenyi István Egyetem, https:// rgdi.sze.hu/images/RGDI/honlapelemei/fokozatszerzesi_anyagok/Ramhap_Szabolcs_doktori_disszertacio.pdf

Rechnitzer J. (2010): A felsőoktatás regionalitása, a régiók és a felsőoktatás. In: Törőcsik M. Kuráth G. (szerk.): Egyetemi marketing, marketing a felsőoktatásban. Pécs: Pécsi Tudományegyetem, $35-48$. 
Székely L. - Szabó A. (szerk.) (2016): Magyar Ifjúság Kutatás 2016. Budapest: Társadalomkutató Kft. http://www.ujnemzedek.hu/sites/default/files/magyar_ifjusag_2016_a4_web.pdf

Törőcsik M. (szerk.) (2015): A Z generáció magatartása és kommunikációja. Pécs: Pécsi Tudományegyetem

Töröcsik M. (2016): A fogyasztói magatartás új tendenciái. Vezetéstudomány, 47, Marketingtudományi Különszám, 19-25. http://unipub.lib.uni-corvinus.hu/2325/1/VT2016n4p19.pdf

Veroszta Zs. (2018): A magyarországi diplomás pályakövetési rendszer kiépülése és eredményei. A hazai felsőoktatás elmúlt 10 évének néhány gazdasági jellemzője. In: Kováts G. -Temesi J. (szerk.): A magyar felsőoktatás egy évtizede 2008-2017. (NFKK Kötetek 2.) Budapest: Budapesti Corvinus Egyetem 202-212. http://unipub.lib.uni-corvinus.hu/3302/ 